Julie Robitaille $\cdot$ Charles Brouillette $\cdot$ Alain Houde Simone Lemieux · Louis Pérusse · André Tchernof Daniel Gaudet · Marie-Claude Vohl

\title{
Association between the PPAR $\alpha$-L162V polymorphism and components of the metabolic syndrome
}

Received: 2 April 2004/ Accepted: 1 June 2004 / Published online: 10 August 2004

(C) The Japan Society of Human Genetics and Springer-Verlag 2004

\begin{abstract}
Genetic factors, alone or in interaction with components of the diet, are thought to be involved in the development of the metabolic syndrome. The objective of our study was first to compare the frequency of the peroxisome proliferator-activated receptor (PPAR) $\alpha$ L162V polymorphism in a sample of men with and without the metabolic syndrome as defined by the National Cholesterol Education Program-Adult Treatment Panel III (NCEP-ATPIII) guidelines, and secondly, to evaluate gene-diet interaction effects on features of the metabolic syndrome. The PPAR $\alpha-\mathrm{L} 162 \mathrm{~V}$ genotype was determined in a sample of 632 men by a polymerase chain reaction-restriction length polymorphism (PCRRFLP)-based method; fat as well as saturated fat intakes were evaluated by a dietitian-administered food frequency questionnaire. The frequency of the V162 allele was similar in men with $(n=281)$ and without $(n=351)$ the metabolic syndrome $\left(\chi^{2}=0.03, p=0.84\right)$ but was
\end{abstract}

J. Robitaille $\cdot$ C. Brouillette $\cdot$ A. Houde $\cdot$ A. Tchernof $\cdot$

M.-C. Vohl ( $\square)$

Lipid Research Center, CHUQ-CHUL Pavilion,

2705 Laurier Blvd, TR-93, Ste-Foy,

QC, Canada, G1V 4G2

E-mail: marie-claude.vohl@crchul.ulaval.ca

Tel.: + 1-418-6564141

Fax: + 1-418-6542145

J. Robitaille · S. Lemieux · A. Tchernof · M.-C. Vohl

Food Science and Nutrition Department,

Laval University, Ste-Foy, QC, Canada

C. Brouillette $\cdot$ L. Pérusse

Department of Social and Preventive Medicine,

Division of Kinesiology, Laval University,

Ste-Foy, QC, Canada

A. Tchernof

Molecular Endocrinology and Oncology Research Center, CHUQ-CHUL Pavilion, Ste-Foy, QC, Canada

D. Gaudet

Community Genomic Medicine Center,

Montreal University and Lipid Clinic,

Chicoutimi Hospital,

Chicoutimi, QC, Canada higher in subjects having simultaneously abdominal obesity, hypertriglyceridemia, and low high-density lipoprotein cholesterol (HDL-C) levels $\left(\chi^{2}=3.73\right.$, $p=0.05$ ). Carriers of the V162 were characterized by higher plasma apolipoprotein B and triglyceride (TG) levels $(p=0.10, p=0.004)$. In a model including the PPAR $\alpha$-L162V polymorphism, fat or saturated fat, its interaction, and covariates (smoking habits, and energy and alcohol intake), the interaction explained a significant percentage of the variance observed in waist circumference $(p<0.05)$. In conclusion, the PPAR $\alpha-\mathrm{L} 162 \mathrm{~V}$ polymorphism alone or in interaction with dietary fat intake is associated with components of the metabolic syndrome.

Keywords PPAR $\alpha \cdot$ Gene-diet interaction - Waist girth $\cdot$ Triglyceride

Abbreviations NCEP-ATPIII: National Cholesterol Education Program-Adult Treatment Panel III • PPARs: Peroxisome proliferator-activated receptors . RXR: Retinoid X receptor PPRE: Peroxisome proliferator response element - Apo B: Apoprotein B PCR-RFLP: Polymerase chain reaction-restriction length polymorphism - L-FABP: Liver fatty acidbinding proteins $\cdot$ FATP-1: Fatty acid-transport protein-1 - AOX: Liver acyl-CoA oxidase - CPT: Carnitine palmitoyltransferase $\cdot$ LPL: Lipoprotein lipase $\cdot$ SR-BI: Scavenger receptor class B type I

\section{Introduction}

The metabolic syndrome was first described by Reaven (1988). More recently, the National Cholesterol Education Program-Adult Treatment Panel III (NCEP-ATPIII) guidelines proposed criteria for the identification of the metabolic syndrome as the presence of three or more of the following components: abdominal obesity, 
hypertriglyceridemia, low high-density lipoprotein cholesterol (HDL-C) concentrations, hypertension, as well as elevated fasting glucose levels (2001). Ford et al. analyzed data from the Third National Health and Nutrition Examination Survey and estimated using the NCEP-ATPIII criteria that the age-adjusted prevalence of the metabolic syndrome in the U.S. population was $23.7 \%$ (Ford et al. 2002). The prevalence was dramatically increased with age, as $43.5 \%$ of the population aged 60-69 years exhibited the syndrome (Ford et al. 2002). Several lifestyle habits may predispose to the metabolic syndrome. Among them, there is evidence that quality and quantity of fatty acids could play a key role in the development of the metabolic syndrome (Grundy et al. 2004; Kris-Etherton et al. 2001). There is also evidence from family and twin studies for the involvement of genetic factors in the etiology of this condition (Bouchard 1995).

Peroxisome proliferator-activated receptors (PPARs) are members of the superfamily of nuclear hormone receptors (1999). To be active, PPARs heterodimerize with the retinoid $\mathrm{X}$ receptor (RXR) and bind to the peroxisome proliferator response element (PPRE) of target genes. Three different PPAR genes have been identified so far $(\alpha, \delta$, and $\gamma)$ (Schoonjans et al. 1996a). PPAR $\alpha$ is mainly expressed in the liver, kidneys, heart, as well as muscle (Auboeuf et al. 1997; Braissant et al. 1996), and it regulates many genes involved in the transport and oxidation of fatty acids (Aoyama et al. 1998; Pineda et al. 1999). Ligands of PPAR $\alpha$ include long-chain fatty acids, eicosanoids, and hypolipidemic drugs such as fibrates (Krey et al. 1997; Lehmann et al. 1997). It has been well documented that fibrates lower plasma triglyceride (TG) and promote elevation of HDL-C concentrations (Staels et al. 1998). Therefore, $\operatorname{PPAR} \alpha$ is a potential candidate gene that may influence the risk of developing the metabolic syndrome.

We previously reported a mutation in the gene encoding PPAR $\alpha$, which results in the substitution of a valine for a leucine in codon 162 (Vohl et al. 2000). In the French Canadian population, the PPAR $\alpha 162 \mathrm{~L} \rightarrow \mathrm{V}$ mutation was associated with higher plasma low-density lipoprotein cholesterol (LDL-C) as well as higher apoprotein B (apo B) levels. The V162 allele was also associated with higher levels of total cholesterol (Flavell et al. 2000; Lacquemant et al. 2000; Tai et al. 2002), LDL-cholesterol (Tai et al. 2002) and apo B levels (Lacquemant et al. 2000; Tai et al. 2002) in other studies. Previous studies demonstrated that although the V162 allele was associated with lipid abnormalities, carriers of the less common allele were not at increased risk of developing cardiovascular disease or diabetes (Flavell et al. 2000; Tai et al. 2002; Vohl et al. 2000). However, none of those studies examined the risk of developing the metabolic syndrome. Furthermore, since fatty acids are ligands for PPAR $\alpha$, we hypothesized that the effect of the PPAR $\alpha-\mathrm{L} 162 \mathrm{~V}$ polymorphism on components of the metabolic syndrome may be influenced by the amount of fat from the diet.
The aim of the present study was to compare the frequency of the PPAR $\alpha-\mathrm{L} 162 \mathrm{~V}$ polymorphism in a sample of men with and without the metabolic syndrome as defined by the NCEP-ATPIII guidelines. The second objective was to evaluate gene-diet interaction effects on features of the metabolic syndrome.

\section{Materials and methods}

\section{Subjects}

The study sample originated from the Saguenay-Lac-StJean (SLSJ) region located in the northeastern part of the province of Quebec. A total of 632 unrelated men were recruited through the Chicoutimi Hospital Lipid Clinic. Subjects were excluded if they were diagnosed with type 2 diabetes, type III dysbetalipoproteinemia, familial hypercholesterolemia, and familial combined hyperlipidemia. Type 2 diabetes was diagnosed according to the WHO criteria (World Health Organization 1985). The diagnosis of familial hypercholesterolemia was based on the following: (1) the presence of a mutation in the LDL receptor gene; (2) the presence of a mutation in the LDL receptor gene in a first-degree relative and either typical tendinous xanthomata or plasma LDL-C above the 95th percentile in the absence of a secondary cause of hypercholesterolemia; or (3) LDL-C above the 95th percentile as well as tendinous xanthomata and a family history of raised plasma LDL-C transmitted in an autosomal dominant pattern. The following criteria were used to exclude subjects with familial combined hyperlipidemia: plasma cholesterol and triglyceride levels above the 95th and 90th percentile for age and gender, and a positive family history of hypertriglyceridemia and/or hypercholesterolemia in first-degree relatives. Type III dysbetalipoproteinemia was diagnosed using the classification of Frederickson, Levy, and Lees, which is based on the visual aspect of the plasma, on total cholesterol and triglyceride levels, and on the results of a plasma electrophoresis. The presence of tendinous xanthomata and the E2/E2 genotype were also useful to diagnose type III dysbetalipoproteinemia. A total of 281 men (44.5\%) presented at least three components of the metabolic syndrome as defined by the NCEP-ATPIII (2001). While $24.1 \%$ presented only three components, $16.6 \%$ showed four components and $3.8 \%$ were characterized by all five features of the metabolic syndrome. Written informed consent was obtained from all participating subjects, and the Medical Ethics Committees of Laval University and Chicoutimi Hospital Lipid Clinic approved the protocol.

\section{Biological variables}

Blood samples free of medication were obtained from an antecubital vein into vacutainer tubes containing EDTA in the morning after a 12-h overnight fast . Blood samples were centrifuged within $1 \mathrm{~h}$ and the plasma frozen 
$\left(-80^{\circ} \mathrm{C}\right)$ until analysis. Plasma cholesterol and TG were measured using enzymatic assays (Burstein and Samaille 1960; McNamara and Schaefer 1987). LDL-C was calculated (Friedewald et al. 1972). The HDL-C fraction was obtained after precipitation of LDL particles in the infranatant with heparin and $\mathrm{MnCl}_{2}$ (Burstein and Samaille 1960; Havel et al. 1955). Apo B concentrations were measured in plasma by the rocket immunoelectrophoretic method of Laurell (1966), as previously described (Moorjani et al. 1987). Serum standards were prepared and calibrated against reference sera obtained from the Centers for Disease Control and Prevention (Atlanta, GA, USA). Plasma glucose concentration was enzymatically measured (Richterich and Dauwalder 1971). Fasting insulinemia was measured by RIA with polyethylene glycol separation (Desbuquois and Aurbach 1971). Body weight, height, and body mass index (BMI) were recorded. Waist circumference was measured according to the procedure recommended at the Airlie conference (Callaway et al. 1988). Resting blood pressure measurements were performed after the subjects had a 5-min rest in a sitting position, phases I and V of Korotkoff sounds being used for systolic and diastolic blood pressures, respectively.

\section{DNA analysis}

Genomic DNA was extracted using the Qiagen extraction kit (San Francisco, USA). Determination of the PPAR $\alpha-L 162 V$ genotype was performed using the polymerase chain reaction-restriction length polymorphism (PCR-RFLP) method as previously described by Vohl et al. (2000).

\section{Nutritional assessment}

A quantitative food frequency questionnaire (FFQ) was used to evaluate fat and saturated fat intake. A trained dietitian administered this 48 -item FFQ to participants. The dietitian asked the subjects to recall average use over the last year. The frequency of food consumption was based on the number of times items consumed per day, per week, or per month. The dietitian also asked to the participants additional information regarding quality and quantity of dietary fat, if necessary. Nutrition Data System for Research (NDS-R) version 4.02 (developed by the Nutrition Coordinating Center, University of Minnesota, Minneapolis, MN, USA, Food and Nutrient Database 30, published in November 1999) was used to calculate nutrients.

\section{Statistical analyses}

Variables not normally distributed (TG, fasting insulin) were $\log _{10}$ transformed. Subjects were grouped on the basis of their PPAR $\alpha-\mathrm{L} 162 \mathrm{~V}$ genotype as homozygotes for the L162 allele (L162/L162) or carriers of the V162 allele (L162/V162 + V162/V162). The association between the PPAR $\alpha-\mathrm{L} 162 \mathrm{~V}$ genotype and components of the metabolic syndrome was evaluated by Student's $t$ test. Analyses of variance were used to adjust for confounding variables. The chi-square $\left(\chi^{2}\right)$ test was used to compare allele frequency between men with and without the metabolic syndrome. Partial Pearson correlation coefficients were used to quantify the age-adjusted interrelationships between components of the metabolic syndrome (HDL-C, TG, waist circumference, fasting glucose levels, and diastolic and systolic blood pressure) and total fat and saturated fat intakes within each genotype group. The gene-diet interactions were evaluated by analyses of covariance using the general linear model procedures. In the model, the PPAR $\alpha$ L162V polymorphism, the fat or saturated fat intake, the interaction term, and confounding variables (age, smoking habits and alcohol and energy intake) were included. The source of variation in metabolic parameters was computed using the type III sum of squares. This sum of squares applies to unbalanced study designs and quantifies the effects of an independent variable after adjustment for all other variables included in the model. All the analyses were performed with SAS (SAS Institute, Cary, NC, USA). A $p$ value $\leq 0.05$ was used to identify a statistically significant result.

\section{Results}

The frequency of the V162 allele reached $10.6 \%$, which is similar to what was previously reported for a nondiabetic study sample also from the region of SLSJ (Vohl et al. 2000). The genotype distribution was not different from Hardy-Weinberg expectations. Table 1 presents subjects' characteristics, including features of the metabolic syndrome, according to the PPAR $\alpha-\mathrm{L} 162 \mathrm{~V}$ genotype. The group of subjects carrying the V162 allele had higher plasma TG levels than L162/L162 homozygotes $(p=0.004)$. Moreover, total apo B concentrations also tended to be higher among carriers of the V162 allele, although these results did not reach statistical significance $(p=0.10)$. Results remained unchanged after adjustment of lipoprotein/lipid, insulin, and glucose levels, as well as blood pressure for the effect of age or for age and BMI. We subsequently compared the frequency of the V162 allele in subjects with and without the metabolic syndrome using criteria defined by the NCEP-ATPIII (2001). The frequency of the V162 allele in the group of men with less than three components of the metabolic syndrome was similar to the one of the group of men with three or more components of the metabolic syndrome $\left(\chi^{2}=0.03, p=0.84\right)$. However, the frequency of the V162 allele was higher in men having simultaneously abdominal obesity (waist circumference above $102 \mathrm{~cm}$ ), hypertriglyceridemia $(>1.7 \mathrm{mmol} / \mathrm{l})$, and low HDL-C concentrations $(<1.04 \mathrm{mmol} / \mathrm{l}) \quad\left[\left(\chi^{2}=3.73, \quad p=0.05\right)\right] . \quad$ The allele 
Table 1 Subjects' characteristics according to the peroxisome proliferator-activated receptor (PPAR) $\alpha-\mathrm{L} 162 \mathrm{~V}$ genotype. Results are expressed as mean $\pm \mathrm{SD}$, number of subjects is shown in parentheses. $B M I$ body mass index, $L D L-C$ low density lipoprotein cholesterol, $H D L-C$ high density lipoprotein cholesterol, $T G$ triglycerides, apo $B$ apoprotein B

\begin{tabular}{lllll}
\hline & L162/L162 & Carriers of the V162 allele $^{\mathrm{a}}$ & $P$ & $P^{*}$ \\
\hline Age (years) & $49.1 \pm 10.4(507)$ & $48.9 \pm 11.0(125)$ & 0.84 & - \\
BMI (kg/m ${ }^{2}$ ) & $27.0 \pm 4.3(503)$ & $26.8 \pm 4.1(124)$ & 0.64 & 0.63 \\
Waist circumference (cm) & $94.6 \pm 11.1(506)$ & $95.2 \pm 12.7(125)$ & 0.63 & 0.60 \\
Total cholesterol (mmol/l) & $5.89 \pm 1.16(507)$ & $6.03 \pm 1.57(125)$ & 0.49 & 0.44 \\
LDL-C (mmol/l) & $3.84 \pm 1.01(465)$ & $3.72 \pm 0.99(105)$ & 0.26 & 0.25 \\
HDL-C (mmol/l) & $1.01 \pm 0.34(506)$ & $0.97 \pm 0.35(123)$ & 0.29 & 0.36 \\
TG (mmol/l) & $2.63 \pm 2.72(507)$ & $3.26 \pm 3.02(125)$ & 0.004 & 0.004 \\
Total apo B (g/l) & $1.15 \pm 0.25(351)$ & $1.20 \pm 0.25(88)$ & 0.10 & 0.11 \\
Glucose (mmol/l) & $5.36 \pm 0.72(504)$ & $5.39 \pm 0.75(121)$ & 0.70 & 0.0003 \\
Diastolic blood & $81.2 \pm 11.3(507)$ & $81.5 \pm 10.1(123)$ & 0.75 & 0.65 \\
pressure (mmHg) & $128.0 \pm 18.2(507)$ & $128.6 \pm 18.1(123)$ & 0.72 & 0.65 \\
Systolic blood & & & 0.70 \\
pressure (mmHg) & & & 0.71 \\
\hline
\end{tabular}

${ }^{\mathrm{a}} 117$ L162/V162 + 8 V162/V162

$P^{*}$ after adjustment for age

$P^{\prime}$ after adjustment for age and BMI

frequency was $8.3 \%$ in men without these three features of the metabolic syndrome $(n=147)$ but reached $13.0 \%$ in men with these characteristics $(n=139)$.

Furthermore, we evaluated the effect of the PPAR $\alpha-$ L162V polymorphism on the relationship between diet and components of the metabolic syndrome. Fat and saturated fat intakes were not different between the two genotype groups, and the mean fat and saturated fat intake in the whole sample were of $92.5 \mathrm{~g} /$ day and $35.0 \mathrm{~g} /$ day, respectively. First, age-adjusted Pearson correlation coefficients were computed for each PPAR $\alpha$ L162V genotype group. Fat intake was significantly associated with waist circumference but only in L162/ L162 homozygotes (Fig. 1). These correlations were not observed among carriers of the V162 allele. Similar results were obtained with saturated fat intake (L162/ L162: $r=0.23, p=0.001$ and for carriers of the V162 allele $r=0.02, p=0.87$, not shown).

To further explore the effect of diet on components of the metabolic syndrome, we performed covariance analyses within a model including the PPAR $\alpha-\mathrm{L} 162 \mathrm{~V}$ polymorphism, fat intake, the interaction term, age, smoking habits, as well as energy and alcohol intake (Table 2). Since age was not a significant contributor to the model, this variable was excluded. However, similar results were obtained when age was included. The polymorphism and the fat $\times$ PPAR $\alpha-\mathrm{L} 162 \mathrm{~V}$ polymorphism, respectively, explained $1.95 \%$ and $2.32 \%$ of the variance in waist circumference $(p<0.05)$ (Table 2). Similar results were obtained with saturated fat intake. The PPAR $\alpha-\mathrm{L} 162 \mathrm{~V}$ polymorphism and its interaction with saturated fat explained $2.05 \%$ and $2.71 \%$ of the variance in waist circumference. There was no other gene-diet interaction effects on other components of the metabolic syndrome (TG, HDL-C, and fasting plasma glucose levels, as well as blood pressure).

Figure $2 a, b$ shows the effect of fat intake or saturated fat intake on waist circumference according to the PPAR $\alpha-\mathrm{L} 162 \mathrm{~V}$ genotype. Low fat or saturated fat
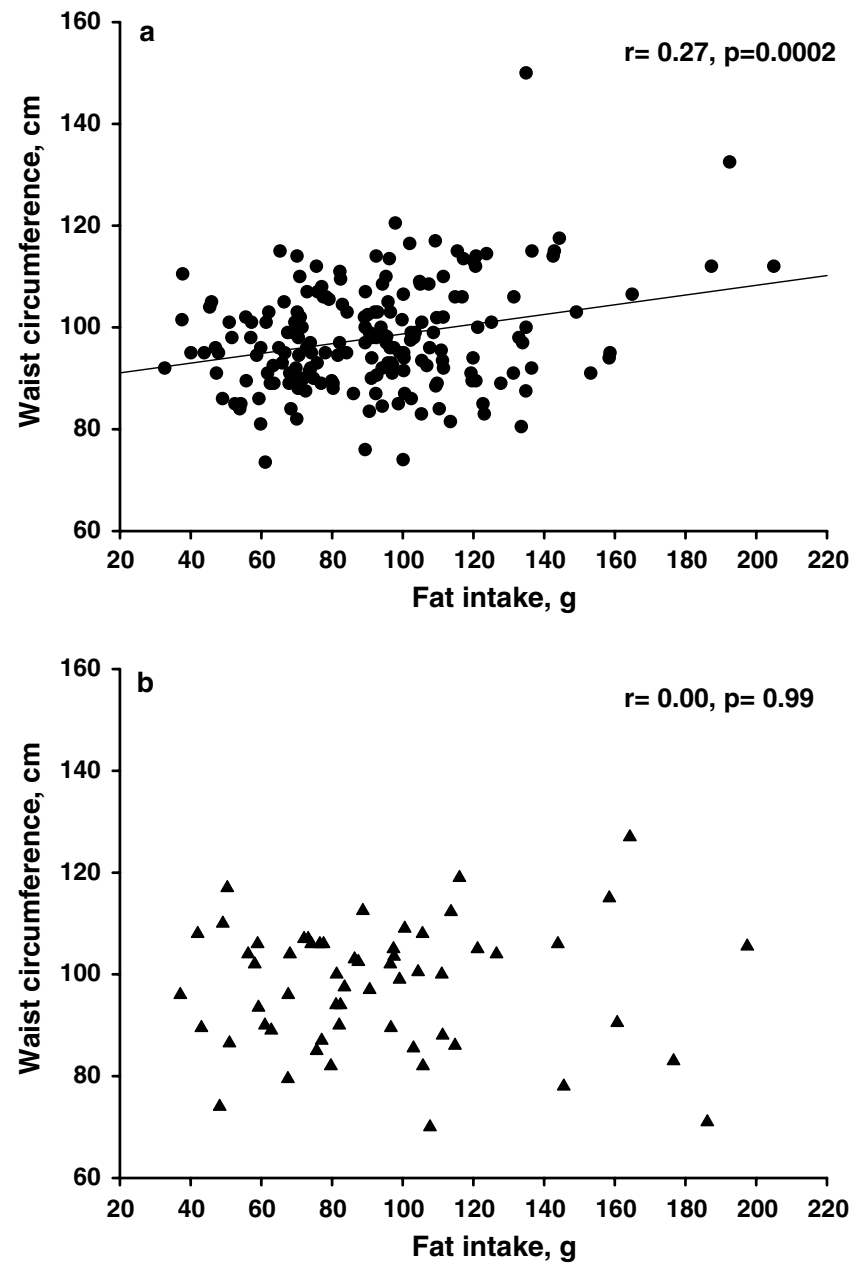

Fig. 1a,b Age-adjusted Pearson correlation between waist circumference and dietary fat intake according to the peroxisome proliferator-activated receptor (PPAR) $\alpha$-L162V genotype. a presents the Pearson correlation in L162/L162 homozygotes. b presents the Pearson correlation in carriers of the V162 allele 
Table 2 Source of variation for waist circumference. $P P A R \alpha-$ L162V peroxisome proliferator-activated receptor, $n s$ not significant

\begin{tabular}{lcl}
\hline & \multicolumn{2}{c}{ Waist circumference $(\mathrm{cm})$} \\
\cline { 2 - 3 } & \% of variance & $P$ value \\
\hline Model 1 & 1.95 & \\
PPAR $\alpha$-L162V & - & 0.04 \\
Fat intake $(f a t)$ & 2.32 & $\mathrm{~ns}$ \\
PPAR $\alpha$-L162V $\times$ fat & - & 0.02 \\
Energy intake & - & $\mathrm{ns}$ \\
Smoking & 3.33 & $\mathrm{~ns}$ \\
Alcohol intake & 12.2 & 0.007 \\
Model & & \\
Model 2 & 2.05 & \\
PPAR $\alpha$-L162V & - & 0.03 \\
Saturated fat intake (SFA) & 2.71 & $\mathrm{~ns}$ \\
PPAR $\alpha$-L162V $\times$ SFA & 2.22 & 0.01 \\
Energy intake & - & 0.03 \\
Smoking & 4.15 & $\mathrm{~ns}$ \\
Alcohol intake & 12.5 & 0.003 \\
Model & & \\
\hline
\end{tabular}

intake was associated with lower waist circumference in L162/L162 subjects. In those subjects, a higher waist circumference was observed in subjects consuming a diet rich in fat or saturated fat. However, among carriers of the V162 allele, these relationships were not observed.

\section{Discussion}

The metabolic syndrome is associated with a greater risk of developing cardiovascular disease, the leading cause of death in Canada and United States (American Heart Association 2002; Heart and Stroke Foundation 1999). Multiple factors are involved in this pathophysiology, and genetic components may play a key role (Bouchard 1995). In this regard, we compared the frequency of the PPAR $\alpha-\mathrm{L} 162 \mathrm{~V}$ polymorphism in a sample of men with and without the metabolic syndrome. To the best of our knowledge, this is the first study to test this association. The frequency of the V162 allele in the population studied was $10.6 \%$, which is similar to the one reported in other Caucasian populations (Vohl et al. 2000), and the frequency of the V162 allele was higher in men simultaneously having abdominal obesity, hypertriglyceridemia, and low HDL-C concentrations. These results suggest that carriers of the V162 allele may be at increased risk to simultaneously exhibit abdominal obesity, hypertriglyceridemia, and hypoalphalipoproteinemia, which are known risk factors for cardiovascular disease.

$\operatorname{PPAR} \alpha$ is a key regulator of fatty acid flux, underlying its possible role in the development of the metabolic syndrome. PPAR $\alpha$ stimulates liver-fatty-acidbinding proteins (L-FABP) and fatty acid transport protein-1 (FATP-1), proteins of the transport and binding of fatty acids (Frohnert et al. 1999; Motojima 2000). Moreover, PPAR $\alpha$ regulates genes involved in fatty acid oxidation such as the liver acyl-CoA oxidase
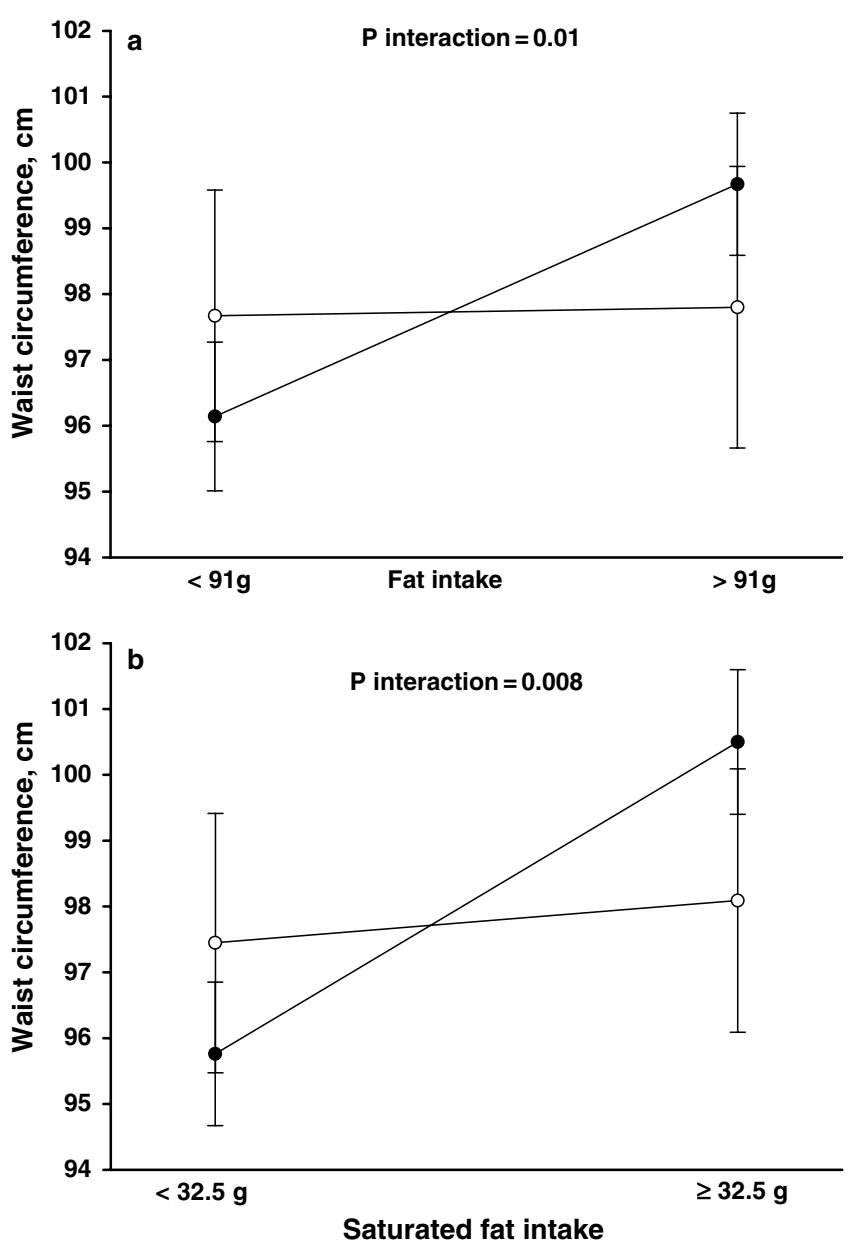

Fig. 2 Effect of the peroxisome proliferator-activated receptor (PPAR) $\alpha$-L162V polymorphism on the association between waist circumference and dietary fat (a) or saturated fat intake (b). Fat as well as saturated fat intake are stratified according to median values of each variable $(91 \mathrm{~g} /$ day and $32.5 \mathrm{~g} /$ day, respectively). Open circles represent V162 carriers (L162/162V + 162V/162V), whereas black circles represent L162/L162 homozygotes. The means \pm SE for each group are presented

(AOX) and the carnitine palmitoyltransferase (CPT) gene (Mascaro et al. 1998; Osumi et al. 1991). Activation of $\operatorname{PPAR} \alpha$ by ligands such as fibrates induces the expression of lipoprotein lipase (LPL) and inhibits the expression of apo CIII, an LPL activity inhibitor (Schoonjans et al. 1996b), which in turn favors lipolysis and TG-rich lipoprotein catabolism, thus decreasing plasma TG levels. PPAR $\alpha$ also induces protein levels of the scavenger receptor (SR) class B type I (SR-BI), a receptor involved in the reverse cholesterol transport pathway (Chinetti et al. 2000).

In the present study, we also observed that carriers of the V162 allele tended to exhibit higher apo B levels, a finding previously reported by Vohl et al. (2000), as well as by Tai et al. (2002). In contrast to other studies, we observed higher plasma TG concentrations among carriers of the V162 allele (Flavell et al. 2000; Tai et al. 2002). It is possible that PPAR $\alpha$ activity is influenced by polymorphisms in genes regulated by $\operatorname{PPAR} \alpha$ and, 
therefore, explain discrepancies between studies. Indeed, Tai et al. showed that the PPAR $\alpha-\mathrm{L} 162 \mathrm{~V}$ polymorphism interacts with the $\mathrm{C} 3238 \mathrm{G}$ polymorphism in the apo CIII gene to modulate plasma levels of TG-rich lipoproteins (Tai et al. 2002). In light of these results, one may believe that the higher frequency of the V162 allele observed in men showing hypertriglyceridemia, abdominal obesity, and low HDL-C levels simply reflects the association with plasma triglycerides. However, a similar trend was obtained when the analysis was performed only with plasma HDL-C and waist circumference $\left(\chi^{2}=3.80, p=0.05\right)$.

Previous studies have shown that the L162V polymorphism was not associated with a greater risk of cardiovascular diseases nor with diabetes (Flavell et al. 2000; Tai et al. 2002; Vohl et al. 2000). However, these studies did not take into account dietary fat intake. It is now well documented that environmental factors such as diet interact with the genetic background to modulate metabolic parameters. Thus, we verified whether dietary fat intake could modulate the association between the PPAR $\alpha-\mathrm{L} 162 \mathrm{~V}$ polymorphism and components of the metabolic syndrome. It was relevant to examine the effect of fat on these associations, considering the role of fatty acids as ligands of PPAR $\alpha$. As observed in the general population, waist circumference was increased with higher intake of dietary fat in L162/L162 homozygotes. However, waist circumference was not influenced by the dietary fatty acids intake among carriers of the V162 allele, suggesting a potential gene-diet interaction effect between the PPAR $\alpha-\mathrm{L} 162 \mathrm{~V}$ polymorphism and fat intake.

It has been demonstrated that long-chain polyunsaturated fatty acids are good ligands for PPAR $\alpha$ (Krey et al. 1997). Fatty acids bind to the PPAR $\alpha$ gene and $\operatorname{PPAR} \alpha$ heterodimerizes with RXR to activate target genes. Further evidence suggests that other fatty acids may transactivate the $\operatorname{PPAR} \alpha$ gene. In a study performed by $\mathrm{Xu}$ et al., saturated fatty acids with chain lengths of 16-18 carbon units were able to bind to $\operatorname{PPAR} \alpha$ to the same extent as polyunsaturated fatty acids with the corresponding lengths, and those with 20 carbon units such as eicosapentanoic and arachidonic acids (Xu et al. 1999). Palmitic (C16) and stearic (C18) acids are the most common saturated fatty acids in the diet, along with myristic acid (C14). Thus, a diet rich in saturated fatty acids may result in a higher transactivation of the PPAR $\alpha$ gene. However, whether plasma concentrations of fatty acids from the diet are sufficient to bind to PPAR $\alpha$ and thus explain the gene-diet interaction observed remain to be defined.

In addition, transient transfection assays using a PPRE-containing reporter gene construct have demonstrated higher transactivation activity in PPAR $\alpha$ carrying the V162 allele when treated with a PPAR $\alpha$ agonist (Flavell et al. 2000; Sapone et al. 2000). Since PPAR $\alpha$ induces fatty acid uptake and catabolism via activation of several mitochondrial fatty acid-catabolizing enzymes (Mascaro et al. 1998; Osumi et al. 1991), increased fat oxidation in carriers of the V162 allele may promote less accumulation of adipose tissue leading to decrease obesity. Recent work by our group has reported lower adiposity among carriers of the V162 allele, and these associations were stronger in women (Bosse et al. 2003). Moreover, PPAR $\alpha$-deficient mice showed a late onset obesity (Costet et al. 1998). It has also been observed in a study by Guerre-Millo et al. (2000) that fenofibrate treatment in C57BL/6 mice (a rodent model of insulin resistance) prevented the high-fat-diet-induced increase in body weight and adipose tissue mass.

Studies evaluating the effect of a gene-diet interaction on variables associated with the metabolic syndrome, such as the present study, will inevitably lead to multiple testing. Indeed, the results should be interpreted with caution and require replication. The study should therefore be considered as exploratory, generating hypotheses rather than testing hypotheses.

In summary, this is the first study to report gene-diet interaction between the PPAR $\alpha-\mathrm{L} 162 \mathrm{~V}$ polymorphism and dietary fat intake. Although this study reports results from a cross-sectional design, these observations provide further information on the role of the PPAR $\alpha$ L162V polymorphism in the metabolic syndrome. These results suggest that carriers of the V162 allele may be at increased risk to develop some components of the metabolic syndrome and indicate that the PPAR $\alpha-\mathrm{L} 162 \mathrm{~V}$ polymorphism possibly modulates the association between dietary fat intake and abdominal obesity. The present results underline the relevance of gene-diet interaction study in the understanding of the etiology of the metabolic syndrome.

Acknowledgements The authors would like to express their gratitude to the subjects for their excellent collaboration. We would like to thank the staffs of the CHUL Lipid Research Center and the Lipid Clinic as well as the Department of Biochemistry and the Cardiology Service of the Chicoutimi Hospital for their dedicated support and assistance. This study was supported by a grant from the Canadian Institutes of Health Research (MOP-44074) and the Heart and Stroke Foundation of Canada. J. Robitaille received a doctoral studentship from the Canadian Institutes of Health Research. C. Brouillette is recipient of a studentship from the "Fonds de la recherche en santé du Québec (FRSQ)." M.C. Vohl and S. Lemieux are research scholars from the "FRSQ." A. Tchernof is a recipient of a new investigator scholarship from the Canadian Institutes of Health Research. D. Gaudet is the chairholder of the Canada Research Chair in Preventive Genetics and Community Genomics (http://www.chaires.gc.ca).

\section{References}

American Heart Association (2002) Heart disease and stroke statistics - 2003 update. Online: http://www.americanheart.org

Aoyama T, Peters JM, Iritani N, Nakajima T, Furihata K, Hashimoto T, Gonzalez FJ (1998) Altered constitutive expression of fatty acid-metabolizing enzymes in mice lacking the peroxisome proliferator-activated receptor alpha (PPARalpha). J Biol Chem 273:5678-5684

Auboeuf D, Rieusset J, Fajas L, Vallier P, Frering V, Riou JP, Staels B, Auwerx J, Laville M, Vidal H (1997) Tissue distribution and quantification of the expression of mRNAs of per- 
oxisome proliferator-activated receptors and liver $\mathrm{X}$ receptoralpha in humans: no alteration in adipose tissue of obese and NIDDM patients. Diabetes 46:1319-1327

Bosse Y, Despres JP, Bouchard C, Perusse L, Vohl MC (2003) The Peroxisome proliferator-activated receptor alpha L162V mutation is associated with reduced adiposity. Obes Res 11:809-816

Bouchard C (1995) Genetics and the metabolic syndrome. Int J Obes 19(Suppl 1):S52-S59

Braissant O, Foufelle F, Scotto C, Dauca M, Wahli W (1996) Differential expression of peroxisome proliferator-activated receptors (PPARs): tissue distribution of PPAR-alpha, -beta, and -gamma in the adult rat. Endocrinology 137:354-366

Burstein M, Samaille J (1960) Sur un dosage rapide du cholesterol lié aux alpha et aux bêta lipoprotéines du sérum. Clin Chem Acta 5:309

Callaway CW, Chumlea WC, Bouchard C, Himes JH, Lohman TG, Martin AD, Mitchell CD, Mueller WH, Roche AF, Seefeldt VD (1988) Standardization of anthropometric measurements. In: Lohman T, Roche A, Martorel R (eds) The Airlie (VA) Consensus Conference. Human Kinetics, Champaign, pp 39-80

Chinetti G, Gbaguidi FG, Griglio S, Mallat Z, Antonucci M, Poulain P, Chapman J, Fruchart JC, Tedgui A, Najib-Fruchart J, Staels B (2000) CLA-1/SR-BI is expressed in atherosclerotic lesion macrophages and regulated by activators of peroxisome proliferator-activated receptors. Circulation 101:2411-2417

Costet P, Legendre C, More J, Edgar A, Galtier P, Pineau T (1998) Peroxisome proliferator-activated receptor alpha-isoform deficiency leads to progressive dyslipidemia with sexually dimorphic obesity and steatosis. J Biol Chem 273:29577-29585

Desbuquois B, Aurbach GD (1971) Use of polyethylene glycol to separate free antibody-bound peptide hormones in radioimmunoassays. J Clin Endocrinol Metab 37:732-738

Executive Summary of The Third Report of The National Cholesterol Education Program (NCEP) (2001) Expert panel on detection, evaluation, and treatment of high blood cholesterol in adults (Adult Treatment Panel III). J Am Med Assoc 285:2486-2497

Flavell DM, Pineda TI, Jamshidi Y, Evans D, Diamond JR, Elkeles RS, Bujac SR, Miller G, Talmud PJ, Staels B, Humphries SE (2000) Variation in the PPARalpha gene is associated with altered function in vitro and plasma lipid concentrations in Type II diabetic subjects [In Process Citation]. Diabetologia 43:673-680

Ford ES, Giles WH, Dietz WH (2002) Prevalence of the metabolic syndrome among US adults: findings from the third national health and nutrition examination survey. J Am Med Assoc 287:356-359

Friedewald WT, Levy RI, Frederickson DS (1972) Estimation of the concentration of low density lipoprotein cholesterol in plasma, without use of the preparative ultracentrifuge. Clin Chem 18:499-502

Frohnert BI, Hui TY, Bernlohr DA (1999) Identification of a functional peroxisome proliferator-responsive element in the murine fatty acid transport protein gene. J Biol Chem 274:3970-3977

Grundy SM, Hansen B, Smith SC Jr, Cleeman JI, Kahn RA (2004) Clinical management of metabolic syndrome: report of the American heart association/national heart, lung, and blood institute/American diabetes Association conference on scientific issues related to management. Circulation 109:551-556

Guerre-Millo M, Gervois P, Raspe E, Madsen L, Poulain P, Derudas B, Herbert JM, Winegar DA, Willson TM, Fruchart JC, Berge RK, Staels B (2000) Peroxisome prolifrator-activated receptor $\alpha$ activators improve insulin sensitivity and reduce adiposity. J Biol Chem 275:16638-16642

Havel RJ, Eder HA, Bragdon JH (1955) The distribution and chemical composition of ultracentrifugally separated lipoprorteins in human serum. J Clin Invest 34:1345-1354

Heart and stroke foundation (1999) The changing face of heart disease and stroke in Canada 2000. Online: http://www.hcsc.gc.ca
Krey G, Braissant O, L'Horset F, Kalkhoven E, Perroud M, Parker MG, Wahli W (1997) Fatty acids, eicosanoids, and hypolipidemic agents identified as ligands of peroxisome proliferator-activated receptors by coactivator-dependent receptor ligand assay. Mol Endocrinol 11:779-791

Kris-Etherton P, Daniels SR, Eckel RH, Engler M, Howard BV, Krauss RM, Lichtenstein AH, Sacks F, St Jeor S, Stampfer M, Grundy SM, Appel LJ, Byers T, Campos H, Cooney G, Denke MA, Kennedy E, Marckmann P, Pearson TA, Riccardi G, Rudel LL, Rudrum M, Stein DT, Tracy RP, Ursin V, Vogel RA, Zock PL, Bazzarre TL, Clark J (2001) AHA scientific statement: summary of the scientific conference on dietary fatty acids and cardiovascular health. Conference summary from the nutrition committee of the American heart association. J Nutr 131:1322-1326

Lacquemant C, Lepretre F, Pineda TI, Manraj M, Charpentier G, Ruiz J, Staels B, Froguel P (2000) Mutation screening of the PPARalpha gene in type 2 diabetes associated with coronary heart disease. Diabetes Metab 26:393-401

Laurell CB (1966) Quantitative estimation of proteins by electrophoresis in agarose gel containing antibodies. Anal Biochem 15:42

Lehmann JM, Lenhard JM, Oliver BB, Ringold GM, Kliewer SA (1997) Peroxisome proliferator-activated receptors alpha and gamma are activated by indomethacin and other non-steroidal anti-inflammatory drugs. J Biol Chem 272:3406-3410

Mascaro C, Acosta E, Ortiz JA, Marrero PF, Hegardt FG, Haro D (1998) Control of human muscle-type carnitine palmitoyltransferase I gene transcription by peroxisome proliferatoractivated receptor. J Biol Chem 273:8560-8563

McNamara JR, Schaefer EJ (1987) Automated enzymatic standardized lipid analyses for plasma and lipoprotein fractions. Clin Chim Acta 166:1-8

Moorjani S, Dupont A, Labrie F, Lupien PJ, Brun D, Gagné C, Giguère M, Bélanger A (1987) Increase in plasma high-density lipoprotein concentration following complete androgen blockage in men with prostatic carcinoma. Metabolism 36:244-250

Motojima K (2000) Differential effects of PPARalpha activators on induction of ectopic expression of tissue-specific fatty acid binding protein genes in the mouse liver. Int $\mathbf{J}$ Biochem Cell Biol 32:1085-1092

Nuclear Receptor Nomenclature Committee (1999) A unified nomenclature system for the nuclear receptor superfamily. Cell 97:161-163

Osumi T, Wen JK, Hashimoto T (1991) Two cis-acting regulatory sequences in the peroxisome proliferator-responsive enhancer region of rat acyl-CoA oxidase gene. Biochem Biophys Res Commun 175:866-871

Pineda TI, Gervois P, Staels B (1999) Peroxisome proliferatoractivated receptor alpha in metabolic disease, inflammation, atherosclerosis and aging. Curr Opin Lipidol 10:151-159

Reaven GM (1988) Role of insulin resistance in human disease. Diabetes 37:1595-1607

Richterich R, Dauwalder H (1971) Zur bestimmung der plasmaglukosekonzentration mit der hexokinase-glucose-6-phosphatdehydrogenase-method. Schweiz Med Wochenschr 101:615-618

Sapone A, Peters JM, Sakai S, Tomita S, Papiha SS, Dai R, Friedman FK, Gonzalez FJ (2000) The human peroxisome proliferator-activated receptor alpha gene: identification and functional characterization of two natural allelic variants. Pharmacogenetics 10:321-333

Schoonjans K, Staels B, Auwerx J (1996a) Role of the peroxisome proliferator-activated receptor (PPAR) in mediating the effects of fibrates and fatty acids on gene expression. J Lipid Res 37:907-925

Schoonjans K, Staels B, Auwerx J (1996b) The peroxisome proliferator activated receptors (PPARS) and their effects on lipid metabolism and adipocyte differentiation. Biochim Biophys Acta 1302:93-109

Staels B, Dallongeville J, Auwerx J, Schoonjans K, Leitersdorf E, Fruchart JC (1998) Mechanism of action of fibrates on lipid and lipoprotein metabolism. Circulation 98:2088-2093 
Tai ES, Demissie S, Cupples LA, Corella D, Wilson PW, Schaefer EJ, Ordovas JM (2002) Association between the PPARA L162V polymorphism and plasma lipid levels: the Framingham offspring study. Arterioscler Thromb Vasc Biol 22:805-810

Vohl MC, Lepage P, Gaudet D, Brewer CG, Betard C, Perron P, Houde G, Cellier C, Faith JM, Despres JP, Morgan K, Hudson TJ (2000) Molecular scanning of the human PPARa gene. Association of the $1162 \mathrm{v}$ mutation with hyperapobetalipoproteinemia. J Lipid Res 41:945-952
World Health Organization (1985) Diabetes mellitus: report of a WHO study group. Geneva, World Health Organization Technical Report Series, No. 727

Xu HE, Lambert MH, Montana VG, Parks DJ, Blanchard SG, Brown PJ, Sternbach DD, Lehmann JM, Wisely GB, Willson TM, Kliewer SA, Milburn MV (1999) Molecular recognition of fatty acids by peroxisome proliferator-activated receptors. Mol Cell 3:397-403 